\title{
Investigation of The Interaction Between Milk Urea Nitrogen (MUN) and Some Parameters in Determining The Level of Nutrition in Dairy Cows
}

\author{
Mehmet TAYTAK 1 , Ismail BAYRAM2* \\ ${ }^{1}$ Agriculture Engineer, Kamer Feed Production, Afyonkarahisar - Turkey \\ ${ }^{2}$ Dep. Of Animal Nutrition, Faculty of Veterinary Medicine, Afyon Kocatepe University, Afyonkarabisar - Turkey
}

\begin{abstract}
This study was carried out to determine the relationship between the amount of Milk Urea Nitrogen (MUN) and nutritional level in dairy cows. The research material was milk samples which were collected from 100 different commercial dairy farms. Three groups were assigned according to the milk analysis in the experiment. Group A, those having normal MUN values between 12-16 mg / $\mathrm{dl}$ in milk samples, group B, those having less MUN value and group C, those having high MUN value. Apart from this acetone, Beta hydroxy butyric acid (BHBA), total solid matter, fat, fat-free dry matter, crude protein (CP),true protein (TP), lactose, saturated fatty acids (SFA), total unsaturated fatty acids (TUFA), Polyunsaturated fatty acid (PUFA), Monounsaturated fatty acid (MUFA) and aflatoxin M1 values measured in milk and these were compared with low, normal and high MUN levels. In the study the MUN values of the groups were 14.46, 10.05 and $20.15 \mathrm{mg} / \mathrm{dl}$ respectively. At the end of the study, although the differences between the groups' acetone values were statistically significant $(\mathrm{P}<0.05)$, the values of all three groups were among the normal acetone values determined for dairy cows. Moreover, there were differences in milk regarding BHBA, fat, CP,TP, SFA, MUFA and AFM1 values $(\mathrm{P}<0.01)$ between the groups. As a concluded that some further detailed studies are required to get to know a deeper understanding of MUN levels in milk cows between acetone, BHBA and other parameters and metabolic diseases.
\end{abstract}

Keywords: Dairy cow, MUN, Nutritional level

\section{Sütçü İneklerde Beslenme Seviyesinin Belirlenmesinde, Sütte Üre Azotu (MUN) ile Bazı Parametreler Arasındaki Etkileşimin Araştırılması}

ÖZ

$\mathrm{Bu}$ araştırma, süt ineklerinde süt üre azotu miktarı ile beslenme düzeyi arasındaki ilişkinin belirlenmesi amacıyla gerçekleştirilmiştir. Araştırmanın materyalini 100 farklı süt ineği işletmesinden toplanan süt numuneleri oluşturmuştur. Araştırmada sütte yapılan analizlere göre 3 grup oluşturulmuştur. Alınan süt numunelerinde MUN değerleri 12-16 mg/dl arasında olanlar normal (grup A) bu değerin altında olanlar düşük (grup B) üzerinde olanlar ise yüksek (grup C) olarak kabul edilmiştir. Ayrıca sütte ölçülen aseton ve beta hidroksi bütirik asit (BHBA) değerlerinin yanı sıra toplam katı madde, yağ, yağsız kuru madde, ham protein, gerçek protein, laktoz, doymuş yağ asidi, toplam doymamış yağ asitleri (TUS), çoklu doymamıs yağ asitleri (PUFA), tekli doymamış yağ asitleri (MUFA) ve aflatoksin M1 seviyelerine göre düşük, normal ve yüksek üre azotu değerleri ile karşılaştırılmıştır. Araştırmada, grupların MUN değerleri sırasıyla: 14.46, 10.05 ve 20.15 $\mathrm{mg}$ /dl'dir. Araştırma sonunda grupların aseton değerleri arasındaki farklılıklar istatistik olarak anlamlı olmasına $(\mathrm{P}<0.05)$ rağmen her üç grubun değerleri de süt inekleri için belirlenen normal aseton değerleri arasındadır. Benzer şekilde sütte BHBA, yağ, ham protein, gerçek protein, doymuş yağ asitleri, MUFA ve AFM1 değerleri açısından gruplar arasında anlaml farklılıklar bulunmaktadır $(\mathrm{P}<0.01)$. Sonuç olarak süt ineklerinde MUN değeri, aseton, BHBA ve diğer parametreler ile metabolik hastalıklar arasındaki ilişkileri anlamak için daha ayrıntılı çalışmalara ihtiyaç bulunmaktadır.

Anahtar Kelimeler: Süt ineği, MUN, Beslenme düzeyi

To cite this article: Taytak M. Bayram I. Investigation of The Interaction Between Milk Urea Nitrogen (MUN) and Some Parameters in Determining The Level of Nutrition in Dairy Cows. Kocatepe Vet J. (2019) 12(3):246-253.

Submission: 01.02.2019 Accepted: 07.08.2019 Published Online: 16.08.2019

ORCID ID; MT: 0000-0002-5090-7474 IB: 0000-0002-9993-7092

*Corresponding author e-mail: ibayram1965@gmail.com 


\section{INTRODUCTION}

Urea (Latin: Urea, Pura) is an organic compound having formula $\mathrm{H}_{2} \mathrm{~N}-\mathrm{CO}-\mathrm{NH}_{2}$ (Barros et al. 2019). Urea contains carbon, nitrogen, oxygen and hydrogen, it is a common of blood and other body fluids (Ferguson 2000). Urea is a final product of protein metabolism and is synthesized from ammonia in the liver. Animals convert excessive ammonia to urea because ammonia is toxic while urea is non-toxic. The concentration of urea in milk is called Milk Urea Nitrogen (MUN) whereas the concentration of urea nitrogen in the blood is called Blood Urea Nitrogen (BUN) since the urea is readily distributed from the blood in the mammary gland passing to the milk, changes in BUN are also reflected in MUN (Powell et al. 2011).

There is limited information about the factors affecting the MUN level in dairy cows. Some researchers have found that the difference between breed, fat and protein levels of milk (Bruhn and Franke 1977), milk NPN level (Cerbulis and Farrell 1975), plasma urea nitrogen (Barton et al. 1996), but some researchers (Carlsson and Pehrson 1993) reported that breed has no effect on mentioned properties. The cows in their first lactation have relatively lower MUN values than the second or subsequent lactations (Carroll et al. 1988, Barton et al. 1996). However MUN was reported to be lower in heifers as compared to that in older cows (Canfield et al. 1990, Grexton 1999), some investigators reported that age had no effects on MUN level (Hof et al. 1997, Eicher et al. 1999). A negative correlation was found between MUN level and high somatic cell count (SCC) and NPN (Ng-Kwai-Hang et al. 1985). The MUN level can be affected by rumen degredable protein (RDP) or rumen undegredable protein (RUP) intake, water consumption, non-structural carbohydrate content of diet, dry matter intake, feeding time, feeding method (Total mixture ration, TMR or free choice feeding), liver and kidney function of animal (Amaral-Phillips 2009). Season also affects the MUN level. Abdouli et al. (2008) reported that highest MUN levels were determined in spring (between April and June) $(17.13 \mathrm{mg} / \mathrm{dl}$ ) whereas the lowest MUN value was reported in winter (JanuaryMarch) (12.82 mg / dl). Analyze method may affect the level of MUN (Arunvipas et al. 2003).Number of Daily milking (Hutjens and Chase 2004) and milking time also affects MUN levels (Gustafsson and Palmquist 1993). Some researchers observed that supplemental glycerol decreased MUN (Sederevicius et al. 2008).

There is a negative relationship between energy level of diet and MUN as it was found by Kirchgessner et al. (1986) that a decreasing on diet energy was a limitation in the energy level of the ration increases the MUN level. Energy / protein level of diet is another factor that affects MUN as it was reported by Depatie (2000), that the energy / protein ratio affected the MUN value more than the total dry matter, crude protein, RDP and RUP or even energy in the rumen. The normal MUN value varies between $12-16 \mathrm{mg} / \mathrm{dl}$, depending on plenty of factors. Abdouli et al. (2008) reported that the cows kept in the Mediterranean conditions, their MUN level was found to be 30.39 $\mathrm{mg} / \mathrm{dl}$. On the other hand, different amounts of MUN have been reported eg: $15-17 \mathrm{mg} / \mathrm{dl}$ (Wambugu et al. 1998), 20.43-32.49 mg/dl (Frank and Swensson 2002), $11.15 \mathrm{mg} / \mathrm{dl}$ (Arunvipas et al. 2008) and 12.7$13.9 \mathrm{mg} / \mathrm{dl}$ (Meeske et al. 2009).

A study was conducted to determine the effect of different factors on milk components in the dairy cows of 3219 Holstein in Korea. MUN concentration in dairy cows in Korea was found to be between $16.68 \pm 5.87 \mathrm{mg} / \mathrm{dl}$. In addition, milk yield, milk fat content, milk protein content and SCC were found negatively correlated (Yoon et al. 2004).

In the light of this information, the aim of this study was to investigate the interaction between milk urea nitrogen and some other milk parameters such as BHBA, aceton, fat, protein, lactose SFA,MUFA,PUFA and AFM1 in dairy cows.

\section{MATERIAL and METHODS}

A total of 400 milk samples were colleceted for four times from 100 different dairy farms in Afyonkarahisar, Turkey. The collected milk was placed in $50 \mathrm{ml}$ sterile tubes and milk sample protection tablets (Broad Spectrum Microtabs, Bentley Mercer) were added to each sample to prevent spoilage. These tablets allowed the column to remain intact at $+4{ }^{\circ} \mathrm{C}$ until analysis was performed.

Milk Urea Nitrogen (MUN), Beta Hydroxy Butyric Acid (BHBA), acetone, total solids, fat, fat-free dry matter, crude protein, true protein, lactose, saturated fatty acid (SFA), Total unsaturated fatty acids (TUS), MUFA, PUFA and Aflatoxin M1 (AFM1) values were analyzed by using infrared spectrophotometry device (Milkoscan FT 120 FOSS lab., Denmark). Three groups were assigned according to the milk analysis in the experiment. Group A, those having normal MUN values between 12-16 mg / dl in milk samples, group B, those having less MUN value and group $\mathrm{C}$, those having high MUN value. The measured parameters were compared with low, normal and high MUN values. Ingredients and composition of diets used according to the experimental groups are shown in Table 1.

Shapiro-Wilk test was used to determine whether the model data were distributed normally. The homogeneity of variance was determined by the Levene test. Logarithmic transformation was applied 
to data not showing normal distribution. Data analysis was performed in SPSS package program. One-way analysis of variance (ANOVA) was used to compare the differences between the groups. TukeyKramer test was used as a post-hoc test to determine the difference between the groups. Research data were evaluated with SPSS version 6 (SPSS 1993). The significance level was assumed as $(\mathrm{P}<0.05)$. It is expressed as mean \pm SEM in the tables.

\section{RESULTS}

In this study, total solids matter levels of the groups were found as $11.76 \%, 11.53 \%$ and $11.49 \%$ respectively. These results were statistically significant $(\mathrm{P}<0.001)$. Total solids matter level of group A were found to be higher than the other groups. Group A $(4.07 \%)$ had higher fat levels than the other groups $(3.88 \%$ and $3.75 \%)$. This result was statistically significant $(\mathrm{P}<0.001)$. The fat-free dry matter levels in groups were $7.58 \%, 7.50 \%$ and $7.60 \%$ respectively. These results were not statistically significant. Crude protein and true protein levels of groups were 3.09\%, $3.01 \%, 3.11 \%$ and $2.92 \%, 2.84 \%, 2.93 \%$, respectively. These results are statistically significant $(\mathrm{P}<0.001)$ and $(\mathrm{P}<0.001)$. There is no differencies on milk lactose levels between the groups. Lactose values of the groups were determined as $4.38 \%, 4.39 \%$ and $4.41 \%$ respectively. The acetone values of the experiment groups were $0.282,0.276$ and $0.256 \mathrm{mmol} / \mathrm{L}$ respectively. These results were statistically different $(\mathrm{P}<0.05)$ and also are within normal range for healthy dairy cows. The other parameters in milk were statistically significant $(\mathrm{P}<0.001)$ such as BHBA, SFA, TUS, MUFA and AFM1. No difference was found between the groups for the PUFA value. The parameters of the experimental groups in milk are shown in Table 2 and Table 3.

Table 1. Ingredients compositions of the experimental diets.

\begin{tabular}{|c|c|c|c|}
\hline \multicolumn{4}{|c|}{ EXPERIMENTAL GROUPS } \\
\hline Feedstuffs (DM\%) & $\mathbf{A}$ & $\mathbf{B}$ & $\mathbf{C}$ \\
\hline Corn silage & 34 & 33,5 & 35 \\
\hline Alfalfa hay & 13,5 & 17 & 20 \\
\hline Barley straw & 9 & 4,5 & 5 \\
\hline Sugar beet pulp & 2,5 & 2,5 & 2,5 \\
\hline Barley grain & 7 & 11 & 0 \\
\hline Concentrate feed $(21 \% \mathrm{CP})$ & 34 & 31,5 & 37,5 \\
\hline \multicolumn{4}{|l|}{ Calculated values (DM \%) } \\
\hline Crude Protein & 14,45 & 14,36 & 14,91 \\
\hline Energy, ME (Mcal/kg)* & 2,75 & 2,82 & 2,69 \\
\hline Ether extract & 3,18 & 3,20 & 3,17 \\
\hline Starch & 27,18 & 29,58 & 21,44 \\
\hline NFC & 38,49 & 42,64 & 33,65 \\
\hline NDF & 36,35 & 34,56 & 38,35 \\
\hline $\mathrm{ADF}$ & 22,45 & 21,05 & 23,63 \\
\hline ADL & 2,92 & 2,72 & 2,84 \\
\hline
\end{tabular}

NFC: Non Fiber Carbohydrates, NDF: Notr detergent fiber, ADF: Acid detergent fiber, ADL: Acid detergent lignin,

* Metabolisable energy (ME) are calculated from NRC (2001).

Table 2. Interaction between MUN and Total Solid Matter, Fat, - Free Matter, Crude Protein, True Protein and Lactose of milk in dairy cows (Mean \pm SEM; $\mathrm{n}=400)$

\begin{tabular}{|c|c|c|c|c|c|c|c|}
\hline Group & $\begin{array}{l}\text { Total Solid } \\
\text { Matter, } \%\end{array}$ & Fat, $\%$ & $\begin{array}{c}\text { Fat Free Dry } \\
\text { Matter, } \%\end{array}$ & $\begin{array}{c}\text { Crude } \\
\text { Protein, } \%\end{array}$ & $\begin{array}{c}\text { True } \\
\text { Protein, } \%\end{array}$ & Lactose, $\%$ & $\begin{array}{l}\text { Urea, } \\
\mathrm{mg} / \mathrm{dl}\end{array}$ \\
\hline & $\mathrm{x}^{-} \pm S \mathrm{x}^{-}$ & $\overline{x^{-}} \pm S x^{-}$ & $\mathrm{x}^{-} \pm S \mathrm{x}^{-}$ & $\bar{x} \pm S x^{-}$ & $\bar{x} \pm S x^{-}$ & $\bar{x}^{-} \pm S x^{-}$ & $\bar{x} \pm S x^{-}$ \\
\hline A & $11,76 \pm 0,05^{\mathrm{a}}$ & $4,07 \pm 0,04^{a}$ & $7,58 \pm 0,02$ & $3,09 \pm 0,01^{\mathrm{a}}$ & $2,92 \pm 0,01^{\mathrm{a}}$ & $4,38 \pm 0,02$ & $14,46 \pm 0,19^{c}$ \\
\hline B & $11,53 \pm 0,07 \mathrm{~b}$ & $3,88 \pm 0,06^{\mathrm{b}}$ & $7,50 \pm 0,03$ & $3,01 \pm 0,02^{\mathrm{b}}$ & $2,84 \pm 0,02^{\mathrm{b}}$ & $4,39 \pm 0,03$ & $10,05 \pm 0,23^{b}$ \\
\hline $\mathrm{C}$ & $11,49 \pm 0,06^{\mathrm{b}}$ & $3,75 \pm 0,05^{\mathrm{b}}$ & $7,60 \pm 0,03$ & $3,11 \pm 0,01^{\mathrm{a}}$ & $2,93 \pm 0,01^{\mathrm{a}}$ & $4,41 \pm 0,02$ & $20,15 \pm 0,46^{a}$ \\
\hline $\mathbf{P}$ & 0,001 & 0,001 & 0,087 & 0,001 & 0,001 & 0,646 & 0,001 \\
\hline
\end{tabular}


Table 3. Interaction between MUN and Aceton, BHBA, SFA, TUS,MUFA,PUFA and AFM1 of milk in dairy cows $($ Mean \pm SEM; $\mathrm{n}=400)$

\begin{tabular}{|c|c|c|c|c|c|c|c|}
\hline \multirow{3}{*}{ Group } & \multirow{2}{*}{$\begin{array}{l}\text { Aceton } \\
\mathrm{mmol} / \mathrm{L}\end{array}$} & \multicolumn{3}{|c|}{ Saturated Fatty } & \multirow[b]{2}{*}{ MUFA } & \multirow[b]{2}{*}{ PUFA } & \multirow[b]{2}{*}{ AFM1, ppt } \\
\hline & & BHBA & Acids & TUS & & & \\
\hline & $\overline{x^{-}} \pm S \mathrm{x}^{-}$ & $\bar{x} \pm S x^{-}$ & $\bar{x} \pm S x^{-}$ & $\bar{x} \pm S x^{-}$ & $\bar{x} \pm S x^{-}$ & $\bar{x} \pm S x^{-}$ & $\mathrm{x}^{-} \pm S \mathrm{x}^{-}$ \\
\hline A & $0,282 \pm 0,005^{a}$ & $0,120 \pm 0,004^{\mathrm{a}}$ & $3,048 \pm 0,004^{b}$ & $1,336 \pm 0,013^{a}$ & $1,26 \pm 0,01^{\mathrm{a}}$ & $0,254 \pm 0,003$ & $31,68 \pm 1,35^{c}$ \\
\hline B & $0,276 \pm 0,010^{\mathrm{ab}}$ & $0,086 \pm 0,005^{b}$ & $2,890 \pm 0,013^{a}$ & $1,348 \pm 0,018^{a}$ & $1,24 \pm 0,02^{\mathrm{a}}$ & $0,250 \pm 0,005$ & $19,43 \pm 0,96^{\mathrm{b}}$ \\
\hline C & $0,256 \pm 0,006^{b}$ & $0,080 \pm 0,004^{b}$ & $2,790 \pm 0,011^{\mathrm{c}}$ & $1,179 \pm 0,009 \mathrm{~b}$ & $1,09 \pm 0,01^{b}$ & $0,246 \pm 0,004$ & $42,16 \pm 0,91^{a}$ \\
\hline $\mathbf{P}$ & 0,021 & 0,001 & 0,001 & 0,001 & 0,001 & 0,368 & 0,001 \\
\hline
\end{tabular}

SFA: Saturated fatty acids, BHBA: Betahydyroxi bütyric acid, TUS: Total unsaturated fatty acids, MUFA: Mono unsaturated fatty acids: PUFA: Poly unsaturated fatty acids, AFM1: Aflatoxin $\mathrm{M}_{1}$

\section{DISCUSSION}

The interaction between the nutrient levels in milk (fat, protein, lactose) and metabolic parameters (urea nitrogen, BHBA, acetone) were investigated in this study. In fact, these two concepts are very irrational and metabolic parameters are mostly secondary. As is the case in many regions of the world, milk is the only nutrient parameter to be determined. However, metabolic parameters give important information about the overall health status of the herd as well as reflects the herd health.

MUN, being of very much importance in metabolism, is an important parameter especially for protein metabolism and it gives very accurate information about the protein contents in nutrition of an animal. (Jonker et al. 1998). If the energy level of the ration is sufficient, the MUN level would be a reliable indicator of whether the dairy cattle are balanced in terms of protein or not, and they are a reliable indicator in revealing the excess or deficit (Ide et al. 1966, Roseler et al. 1993, Broderick and Clayton 1997, Hof et al. 1997, Jonker et al. 1998). In addition, BUN and MUN are highly correlated each other (Thorton,1970; Ciszuk and Gebregziabher,1994). Jonker et al. (1998) reported that urinary and fecal excretion, intake, and utilization efficiency for $\mathrm{N}$ level, can be calculated by the mechanism they developed by using MUN and total milk protein level. In line with these findings only the MUN monitoring of the dairy cattle in terms of protein level can be clearly revealed. However, according to many studies on this subject there are different opinions about optimum MUN level. Accordingly, Moore and Varga (1996) and Rajala-Shultz et al. (2001) reported that optimum MUN level was found $10-14 \mathrm{mg} / \mathrm{dl}$ level. In addition, other optimal MUN levels have been reported (10-16 mg / dl; Jonker et al., 1998), 11-17 $\mathrm{mg} / \mathrm{dl}$; Hong et al., 2003). According to the researchers, high level of acceptable MUN is directly related to milk yield. Cows who have high milk yield these have a higher amount of $\mathrm{N}$ that they will consume because of their special feeding kinetics. Therefore, it is more reasonable to adopt 10-14 $\mathrm{mg} / \mathrm{dl}$ for medium and low-yield dairy cattle. In addition, Kohn (2007) 's pilot study with a mean of $12.7 \mathrm{mg} / \mathrm{dl}$ MUN average in flocks, otherwise it is not economic reports that the feeding of the opinion confirms.

The value of MUN is not only affected by the protein level of the ration. The level and type of energy in the ration are also effective on MUN. Because it is necessary to have sufficient fermentable carbohydrates in the environment for the degradation and recombination of the protein in the rumen (Oltner et al. 1985, Moore and Varga 1996, RajalaShultz 2001). One of the important and reliable studies in this situation was of Beckman and Weiss (2005). Researchers reported that when the ratio of NDF-starch increased the level of MUN also increased despite the same protein level and sources. Valerades et al. (2000) reported that in the ration of dairy cattle, instead of high-moist corn, use of alfalfa silage increased the value of MUN. However, NDF digestibility has a large share in this effect. As Kauffman and St-Pierre (2001) reported, the MUN value is not affected by the replacement of the starch sources in the ration with very high digestibility (such as soy shell) raw materials. Furthermore, Jonker et al. (2002) reported that low levels of milk in dairy cattle fed with protein in accordance with the amounts reported in NRC (2001) led to a decrease in milk yield and an increase in MUN value. The researchers correlated the detection of a high level of MUN value in dairy cows with low milk yield to energy insufficiency. Similarly decreasing starch and energy value without increasing protein level and sources of ration and increasing of NDF resources which are difficult to digest increased MUN value.

Another metabolic parameter that indicates health and productivity of dairy cattle is the level of BHBA level in milk because it gives information about the energy metabolism and ketosis susceptibility levels of animals in herd (Enjalbert et al. 2001). Ketosis is an important disorder that appears as a reflection of severe negative energy balance in dairy cattle and has a strong relationship with other metabolic diseases which negatively affects the health and productivity 
of animals (Grummer 1993, Gustafsson et al. 1993, Duffield 2000, Oetzel 2007). The ketosis is manifested by two types clinical and subclinical. The dairy cows with clinical ketosis have a depressive, anorexia, dull and lethargic appearance and a significant decrease in their milk yield (Duffield 2000). However, the subclinical form is very sneaky with having no visible signs except decrease in milk yield which poses significant economic losses to the farmer (Anderson 1988, Oetzel 2007). Duffield (1997) reported that cows with blood BHBA level 1.6 mmol/ 11.8 liters per day; Cows with $1.8 \mathrm{mmol} / 13$ liters; Cows with more than $2 \mathrm{mmol} / \mathrm{l}$ produce 4 liters of milk. As it can be prevented in time, losses due to subclinical ketosis may cause serious economic losses. Because it depends on nutrition, various tests are carried out to reveal this insidious disease, which is generally herd-based, without serious losses. BHBA analysis, which is routinely performed on tank milk, is one of these tests. According to Shultz and Myers (1959) and Andersson (1984), there is a very high correlation between the ketone bodies in the milk and the ketone bodies in the blood. Therefore, analysis in milk instead of blood can be more easily and reliably revealing the incidence of ketosis in herd. Especially, in recent years, studies have been carried out to calculate the correlation between an increasing number of blood and milk BHBA levels (Enjalbert 2001, Van Knegsel 2010, Denis-Robichaud et al.2014). One of the most recent studies on the determination of milk BHBA level by NIR method is Denis-Robichaud et al. (2014). According to this study, the level of BHBA detected in milk above 0.2 mmol / 1 indicates hyperacetonemia, in other words, subclinical ketosis. In the present study, although there was a difference between the groups in terms of milk BHBA levels $(\mathrm{P}<0.05$, Table 2$)$, the level of any group did not exceed $0.20 \mathrm{mmol} / \mathrm{l}$. In other words, if we look at the averages of the groups, we can easily say that there is no danger of subclinical ketosis. There may be several reasons for this. First of all, as reported by Overton and Waldron (2004), subclinical ketosis is a problem of dairy cows that develop immediately after birth and have high milk yield. In the present study, the average daily milk per animal of the samples from which the samples are obtained varies between 21 and 231 / day and a high level of efficiency cannot be mentioned. In addition, the number of new birth animals is less than the herd overall. Therefore, it is understandable that the incidence of subclinical ketosis is low for the farms where the samples are taken. But at the ideal MUN level (12-16 mg / dl, Group A), it is very thoughtprovoking that the level of milk BHBA is lower than that of low $(<12 \mathrm{mg} / \mathrm{dl}$, Group B) and high $(>16$ $\mathrm{mg} / \mathrm{dl}$, Group C) MUN groups. However, in order to be able to express this situation more clearly and to make a healthy interpretation, there is a need for new studies to be carried out in new dairy cows with higher milk yield. However, there is a positive correlation between ketone bodies in blood and milk fat levels. Duffield et al. (1997) reported that milk fat is increased in cows with subclinical ketosis and the ratio of milk fat to protein increases. Milk fat was also found to be high in group $\mathrm{A}$ in which milk BHBA level was high in line with this finding $(\mathrm{P}<0.05)$. Therefore, it can be said that there is a connection between MUN level and milk fat.

However, in some recent studies, the number of studies reporting a close correlation between the fatty acid composition of milk and the negative energy balance and ketone bodies is increasing (Melendez et al. 2016). The origin of the short and medium chain fatty acids in milk fat is acetate, whereas the longchain fatty acids are synthesized from the nonesterified fatty acids circulating in the blood (Bauman and Griinari 2003). Thus, parallel to the rising negative energy balance, the rate of PUFA that make up milk oil increases due to increased blood levels of NEFA and BHBA (Melendez et al. 2016). In our study, while the PUFA values were not different, the MUFA and TUS values were different. MUFA and TUS values were significantly lower in the $\mathrm{C}$ group with higher MUN levels than in the other groups. In addition, milk fat and BHBA levels of group $\mathrm{C}$ were found to be statistically lower in group B and statistically lower in group A than in group A. This decrease in milk fat and BHBA level resulted in a decrease in MUFA and TUS levels. In addition, there was a statistically significant difference between all groups in terms of saturated fatty acids, it was found to be the highest in group A with MUN level in accordance with other parameters and the lowest in group C with high MUN level. The low level of energy, especially the starch level in the ration of group $\mathrm{C}$, may have led to these results. However, the fact that ketosis is not developed due to the low milk yield in the dairy samples is difficult to make a clear interpretation.

The level of acetone in milk is a very useful parameter which can be used in herd health programs to diagnose subclinical ketosis cases and can provide reliable results about energy balance (Mottram et al. 2002, Reist et al. 2000). In milk, acetone level shows a negative correlation with energy balance $(r=-0.64)$ (Clark et al. 2005). The acetone concentration in milk ranges from 0 to $2 \mathrm{mmol} / \mathrm{L}$ and is generally classified as $<0.4 \mathrm{mmol} / \mathrm{L}, 0.41-1.0 \mathrm{mmol} / \mathrm{L}, 1.01$ $2.0 \mathrm{mmol} / \mathrm{L}$ and $>2.0 \mathrm{mmol} / \mathrm{L}$ (Mottram et al. 2002). The acetone concentration in milk is $<0.7$ mmol / L, indicating that the dairy cows are extremely healthy, that 0.7-1.4 mmol / L can be ketosis, and $>1.4 \mathrm{mmol} / \mathrm{L}$ ketosis. When the acetone levels of the experimental groups were reviewed, although there were statistically significant differences between the groups, the acetone values of all three groups were among the values reported in dairy cows (Mottram et al. 2002). In the research, 
AFM1 values obtained as a result of analysis in milk were statistically different $(\mathrm{P}<0.01)$. However, the values of all groups are within normal limits. There are legally tolerable limit values due to the very significant risks that aflatoxins can cause on human health. This limits the Codex Alimentations for AFM 1 levels of $500 \mathrm{ng} / \mathrm{kg}$ (PPT), the European Union and in Turkey and $50 \mathrm{ng} / \mathrm{kg}$ (PPT) d (Şanlı 1995, Anonymous 2002, Anonymous 2006).

\section{CONCLUSION}

In this study, it was investigated how the other parameters were affected in the milk with different (high, normal, low) MUN levels. Accordingly, it was found that the MUN level was directly affected by the energy level of the ration, and even if the protein was very well calculated in the dairy cattle fed with insufficient energy, the bioavailability would decrease and the MUN level would increase and the milk fat would decrease. This can lead to serious economic damage, resulting in both loss of yield (milk yield, milk fat, reproductive fertility) and waste of the ration protein. However, there was also a correlation between the level of MUN and the level of BHBA in milk. Although high levels of BHBA in MUN normal levels are thought- provoking, no group has reached the level of clinical or subclinical ketosis. This may be due to the low milk yield of dairy farms. Therefore, according to the data obtained in this study, more extensive studies are needed with the milk samples to be obtained from high milk producers in order to reveal the interaction between MUN and the levels of BHBA, fat, saturated and unsaturated fats in milk.

\section{ACKNOWLEDGEMENT}

The autors thank to Afyon Kocatepe Scientific Research Projects Coordination Unit (AKÜ BAPK) for supporting (Project Number 14.SAĞBIL.17).

\section{REFERENCES}

Abdouli H, Rekik B, Haddad-Boubaker A. Non-nutritional factors associated with milk urea concentrations under Mediterranean conditions. World J Agric Sci. 2008; 4(2):183-188.

Amaral-Philllips, D.M. Milk urea nitrogen-a nutritional evaluation tool. http://www.uky.edu/Ag/AnimalSciences/dairy/exten sion/nut00029.pdf. Accesien date: 15 February 2009.

Andersson L. Subclinical ketosis in dairy cows. Vet Clin North Am Food Anim Pract.1988; 4:233-248.

Andersson L. Concentrations of blood and milk ketone bodies, blood isopropanol and plasma glucose in dairy cows in relation to the degree of hyperketonemia and clinical signs. Zentralbl Veterinarmed A.1984; 31:683-693.

Anonimous. Türk Gıda Kodeksi Gıda Maddelerinde Belirli Bulaşanların Maksimum Seviyelerinin Belirlenmesi Hakkında Tebliğ. Tebliğ No: 2002/63, 23 Eylül 2002 tarihli ve 24885 sayll Resmi Gazete, Ankara. 2002.
Anonimous. EC No: 1881/2006 of 19 December 2006 setting maximum levels for certain contaminants in foodstuffs. Off J Eur Union, 2006; 364: 5-24.

Arunvipas P, Van Leeuwen JA, Dohoo IR, Keefe GP, Burton SA, Lissemore KD. Relationships among milk ureanitrogen, dietary parameters, and fecal nitrogen in commercial dairy herds. The Canadian J Vet Research. 2008;72: 449-453.

Barton BA, Rosario HA, Andersson GW, Grindle BP, Carroll DJ. Effects of dietary crude protein, breed, parity, and health status on the fertility of dairy cows. J Dairy Sci. 1996;79: 2225-2236.

Bauman DE, Griinari JM. Nutritional regulation of milk fat synthesis. Annual Rev Nutr. 2003; 23: 203.

Barros T, Barros T, Reed KF, Olmos Colmenero JJ, Wattiaux MA. Short communication: Milk urea nitrogen as a predictor of urinary nitrogen and urea nitrogen excretions of late-lactation dairy cows fed nitrogenlimiting diets. J Dairy Sci. 2019; Feb; 102(2):1601-1607.

Beckman JL, Weiss WP. Nutrient digestibility of diets with different fiber to starch ratios when fed to lactating dairy cows. J Dairy Sci. 2005; 88(3): 1015-1023.

Broderick GA, Clayton MK. A statistical evaluation of animal and nutritional factors influencing concentrations of milk urea nitrogen. J Dairy Sci. 1997; 80: 2964-2971.

Bruhn JC, Franke AA. Monthly variations in gross composition of California herd milks. J. Dairy Sci. 1977; 60: 696-700.

Canfield RW; Sniffen CJ, Butler WR. Effects of excess degradable protein on postpartum reproduction and energy balance in dairy cattle. J Dairy Sci. 1990; 73: 23422349.

Carlsson J, Pehrson B. The relationship between seasonal variations in the concentration of urea in bulk milk and the production and fertility of dairy herds. J Vet Med. 1993; 40: 205-212.

Carroll DJ, Barton BA, Anderson GW, Smith RD. Influence of protein intake and feeding strategy on reproductive performance of dairy cows. J Dairy Sci. 1988; 71(12): 3470-3481.

Cerbulis J, Farrell HM. Composition of milks of dairy cattle. 1. Protein, lactose, and fat contents and distribution of protein fraction. J Dairy Sci. 1975; 58: 817-827.

Ciszuk AU, Gebregziabher T. Milk urea as an estimate of urine nitrogen of dairy cows and goats. Acta Agric Scand 1994; 44:87-95.

Clark CEF, Fulkerson WJ, Nandra KS, Barchia I, Macmillan KL. The use of indicators to assess the degree of mobilisation of body reserves in dairy cows in early lactation on a pasture-based diet. Livest Prod Sci. 2005;94: 199-211.

Denis-Robichaud J, Dubuc J, Lefebvre D, DesCôteaux L. Accuracy of milk ketone bodies from flow-injection analysis for the diagnosis of hyperketonemia in dairy cows. J Dairy Sci. 2014;97(6): 3364-3370.

Duffield T. Subclinical ketosis in lactating dairy cattle. Veterinary Clinics of North America: Food Anim Practice. 2000; 16(2): 231-253.

Duffield TF. Effects of a monensin controlled release capsule on energy metabolism, health and production in lactating dairy cattle. DVSc-Thesis, 1997; University of Guelph, Ontario, Canada.

Duffield TF, Kelton DF, Leslie KE, Lissemore KD, Lumsden JH. Use of test day milk fat and milk protein 
to detect subclinical ketosis in dairy cattle in Ontario. Canadian Vet J. 1997; 38(11): 713.

Eicher R, Bouchard E, Bigras-Poulin M. Factors affecting milk urea nitrogen and protein concentrations in Quebec dairy cows. Prev Vet Med. 1999; 39: 53-63.

Enjalbert F, Nicot MC, Bayourthe C, Moncoulon R. Ketone bodies in milk and blood of dairy cows: Relationship between concentrations and utilization for detection of subclinical ketosis. J Dairy Sci. 2001;84(3): 583-589.

Ferguson JD. Milk urea nitrogen. 2000; Penn State University extension. USA

Frank B, Swensson C. Relationship between content of crude protein in rations for dairy cows and milk yield, concentration of urea in milk and ammonia emissions. J Dairy Sci. 2002; 85: 1829-1838.

Grexton B. MUN data on Ontario herds offers up some interesting information, Accesien Date: September 2, 1999. http://www.ontdhi.com/mundata.htm

Grummer RR. Etiology of lipid-related metabolic disorders in periparturient dairy cows. J Dairy Sci. 1993; 76(12):38823896.

Gustafsson AH, Carlsson J. Effects of silage quality, protein evaluation systems and milk urea content on milk yield and reproduction in dairy cows. Livestock Prod Sci. 1993; 37: 91-105.

Gustafsson AH, Palmquist DL. Diurnal Variation of Rumen Ammonia, Serum Urea, and Milk Urea in Dairy Cows at High and Low Yields. J Dairy Sci. 1993; 76: 475-484.

Hof G, Vervoorn MD, Lenaers PL, Tamminga S. Milk urea nitrogen as a tool to monitor the protein nutrition of dairy cows. J. Dairy Sci. 1997; 80: 3333-3340.

Hong NTT, Wanapat M, Wachirapakorn C, Pakdee P, Rowlinson P. Effects of timing of initial cutting and subsequent cutting on yields and chemical compositions of cassava hay and its supplementation on lactating dairy cows. Asian Australasian J Anim Sci. 2003; 16(12): 17631769.

Hutjens M, Chase LE. Interpreting milk urea nitrogen (MUN) values Accesien Date: 2004; http://www.extension.org/pages/Interpreting_Milk_ Urea_Nitrogen_(MUN)_ Values.

Ide Y, Shimbayashi K, Yonemura T. Effect of dietary conditions upon serum- and milk-urea nitrogen in cows I. Serum- and milk-urea as affected by protein intake. Jap J Vet Sci. 1966; 28: 321-327.

Jonker JS, Kohn RA, Erdman RA. Using milk urea nitrogen to predict nitrogen excretion and utilization efficiency in lactating dairy cattle. J Dairy Sci. 1998; 81: 2681-269.

Jonker JS, Kohn RA, High J. Use of milk urea nitrogen to improve dairy cow diets. J Dairy Sci. 2002; 85: 939-946.

Kauffman AJ, St-Pierre NR. The relationship of milk urea nitrogen to urine nitrogen excretion in Holstein and Jersey cows. J Dairy Sci. 2001; 84: 2284-2294.

Kirchgessner M, Kreuzer M, Roth-Mailer DA. Milk urea and protein content to diagnose energy and protein malnutrition of dairy cows. Arch Anim Nut. 1986; 36: 192-197.

Kohn R. Use of milk or blood urea nitrogen to identify feed management inefficiencies and estimate nitrogen excretion by dairy cattle and other animals. In 18th Annual Florida Ruminant Nutrition Symposium. 2007; Paper (Vol. 8).
Meeske R, Botha PR, Van der Merwe GD, Greyling JF, Hopkins C, Marais JP. Milk production potential of two ryegrass cultivars with different total non-structural carbohydrate contents. South African J Anim Sci. 2009; 39(1): 15 .

Melendez P, Pinedo P, Bastias J, Marin MP, Rios C, Bustamante C, Duchens M. The association between serum B-hydroxybutyrate and milk fatty acid profile with special emphasis on conjugated lsinoleic acid in postpartum Holstein cows. BMC Veterinary Res. 2016; 12(1): 50 .

Moore DA, Varga G. BUN and MUN: urea nitrogen testing in dairy cattle. Compendium on Continuing Education for the Practising Veterinarian. 1996;18 (12): 712-720.

Mottram T, Velasco-Garcia $M$, Berry $\mathbf{P}$, Richards $\mathbf{P}$, Ghesquiere J, Masson L. Automatic on-line analysis of milk constituents (urea, ketones, enzymes and hormones) using biosensors. Comp Clin Pathol. 2002; 11: 50-58.

Ng-Kwai-Hang KF, Hayes JF, Moxley JE, Monardes HG. Percentages of protein and nonprotein nitrogen with varying fat and somatic cells in bovine milk. J Dairy Sci. 1985; 68: 1257-1262.

NATIONAL RESEARCH COUNCIL - NRC. Nutrient requirements of dairy cattle. 7.ed. Washington: National Academy Press, 2001; 381p.

Oetzel GR. Herd-level ketosis-diagnosis and risk factors. In Proceedings of the 40th annual conference of bovine practitioners. 2007; Vancouver, Canada.

Oltner R, Emanuelson M, Wiktorsson H. Urea concentrations in milk in relation to milk yield, live weight, lactation number and amount and composition of feed given to dairy cows. Livestock Prod Sci. 1985; 12: 47-57.

Overton TR, Waldron MR. Nutritional management of transition dairy cows: strategies to optimize metabolic health. J Dairy Sci. 2004; 105-119.

Powell JM, Wattiaux MA, Broderick GA. Short communication: Evaluation of milk urea nitrogen as a management tool to reduce ammonia emissions from dairy farms. J Dairy Sci. 2014; 94 :4690-4694.

Rajala-Schultz PJ, Saville WJA, Frazer GS, Wittum TE. Association between milk urea nitrogen and fertility in Ohio dairy cows J Dairy Sci. 2001; 84(2): 482-489.

Reist M, Koller A, Busato A, Küpfer U, Blum JW. First ovulation and ketone body status in early postpartum period of dairy cows. Theriogenology. 2000; 54: 685-701.

Roseler DK, Ferguson JD, Sniffen CJ, Herrema J. Dietary protein degradability effects on plasma and milk urea nitrogen and milk nonprotein nitrogen in Holstein cows. J Dairy Sci. 1993; 76: 525-534.

Schultz LH, Myers M. Milk test for ketosis in dairy cows. J Dairy Sci. 1959; 42: 705-710.

Sederevicius A, Kabasinskiene A, Savickis S, Svedaite V, Makauskas S. Milk urea nitrogen as an important indicator of dairy cow: nutrition review. Veterinarjia Ir Zootechnika. 2008; 44(66): 98.

SPSS for Windows. Released 6.0 June 17 1993; Copy right (c. Sps inc. 1989-1993).

Şanlı Y. Mikotoksinler. Veteriner Klinik Toksikoloji, (Ed. Sezai Kaya), sh: 283-306, Medisan Yayınevi, Medisan Yayın Serisi no:21, Ankara.1995 
Thorton RF. Factors effecting the urinary excretion of urea nitrogen in cattle: I. Sodium chloride and water loads. Aust J Agric Res. 1970; 21: 131-144.

Valadares SC, Broderick GA, Valadares RFD, Clayton MK. Effect of replacing alfalfa silage with high moisture corn on nutrient utilization and milk production. J Dairy Sci. 2000; 83: 106-114.

Van Knegsel ATM,. Van der Drift SGA, Horneman M, de Roos APW, Kemp B, Graat EAM. Short communication: Ketone body concentration in milk determined by Fourier transform infrared spectroscopy: Value for the detection of hyperketonemia in dairy cows. J Dairy Sci. 2010; 93: 3065-3069.

Wambugu M, Wahome RG, Gachuiri C, Tanner J, Kaitho R. Evaluation of the use of milk urea nitrogen (MUN) as an indicator of nutritional status of dairy cattle in smallholder farms in kiambu district. Paper presented at the Faculty of Vet. Med. Biennial Conference, Kabete Campus, University of Nairobi, 5-7 August. 1998.

Yoon T, Lee JH, Kim CK, Chung YC, Kim CH. Effects of Milk Production, Season, Parity and Lactation Period onVariations of Milk Urea Nitrogen Concentrationand Milk Components of Holstein Dairy Cows* AsianAustralian J Anim Sci. 2004; 17(4): 479-484. 